\title{
Iron Biogeochemistry in Aquatic Systems: From Source to Bioavailability
}

\author{
Louiza Norman ${ }^{a}$, Damien J. E. Cabanes ${ }^{b}$, Sonia Blanco-Ameijeiras ${ }^{b}$, Sophie A. M. Moisset ${ }^{b}$, and \\ Christel S. Hassler ${ }^{\star a b}$
}

\begin{abstract}
Iron (Fe) is an essential trace element for several key metabolic processes in phytoplankton; however Fe is present in low concentration in many aquatic systems including vast oceanic regions and large lakes. In these systems, Fe can limit the growth of phytoplankton and atmospheric carbon dioxide biological fixation. Indeed Fe limitation exerts a global impact on the carbon cycle and the imprint of aquatic systems on our climate. In order to understand how aquatic systems function and increase our ability to predict their response to changing conditions, it is therefore paramount to understand when and how Fe controls operate. This review presents the complex relationship between Fe chemistry and the biology of surface waters to highlight the parameters defining the forms of $\mathrm{Fe}$ that are accessible for phytoplankton growth (or bioavailable). Particular attention is given to the identification of Fe sources and Fe organic complexation as these, in conjunction with biological recycling and remineralisation, mostly control Fe residence time, chemistry and bioavailability.
\end{abstract}

Keywords: Carbon · Iron · Lake · Limitation · Ocean · Phytoplankton

\section{The Importance of Iron in Aquatic Systems}

Phytoplankton are sensitive to environmental conditions and have a short life span, making them an ideal sentinel to track changes in aquatic systems. Phytoplankton plays a major role in aquatic systems as its biological functioning affects the biogeochemical cycles of carbon $(\mathrm{C})$ and $\mathrm{Fe}$ (Fig. 1) as well as a number of other key elements (i.e. nitrogen $(\mathrm{N})$, silicon $(\mathrm{Si})$, sulphur (S), etc.). By the process of photosynthesis phytoplankton is responsible for up to $40 \%$ of atmospheric carbon dioxide $\left(\mathrm{CO}_{2}\right)$ biological fixation (referred as primary productivity), transforming inorganic carbon into organic forms that sustain the aquatic food web. ${ }^{[1,2]}$ Phytoplankton therefore affects global carbon cycling and plays an important role in the regulation of Earth's climate. However, whereas the oceans are known to be a net sink for atmospheric $\mathrm{CO}_{2}$, the carbon budget for lakes is less clear. ${ }^{[3]}$

\footnotetext{
${ }^{*}$ Correspondence: Prof. C. S. Hassler ${ }^{\mathrm{ab}}$ Tel.: +41223790309

E-mail: Christel.Hassler@unige.ch

aUniversity of Technology Sydney

Plant Functional Biology and Climate Change Cluster PO Box 123

Broadway 2007

NSW, Australia

bUniversity of Geneva

Earth and Environmental Sciences

Institute F.-A. Forel

Marine and Lake Biogeochemistry

10 rte de Suisse

$\mathrm{CH}-1290$ Versoix
}

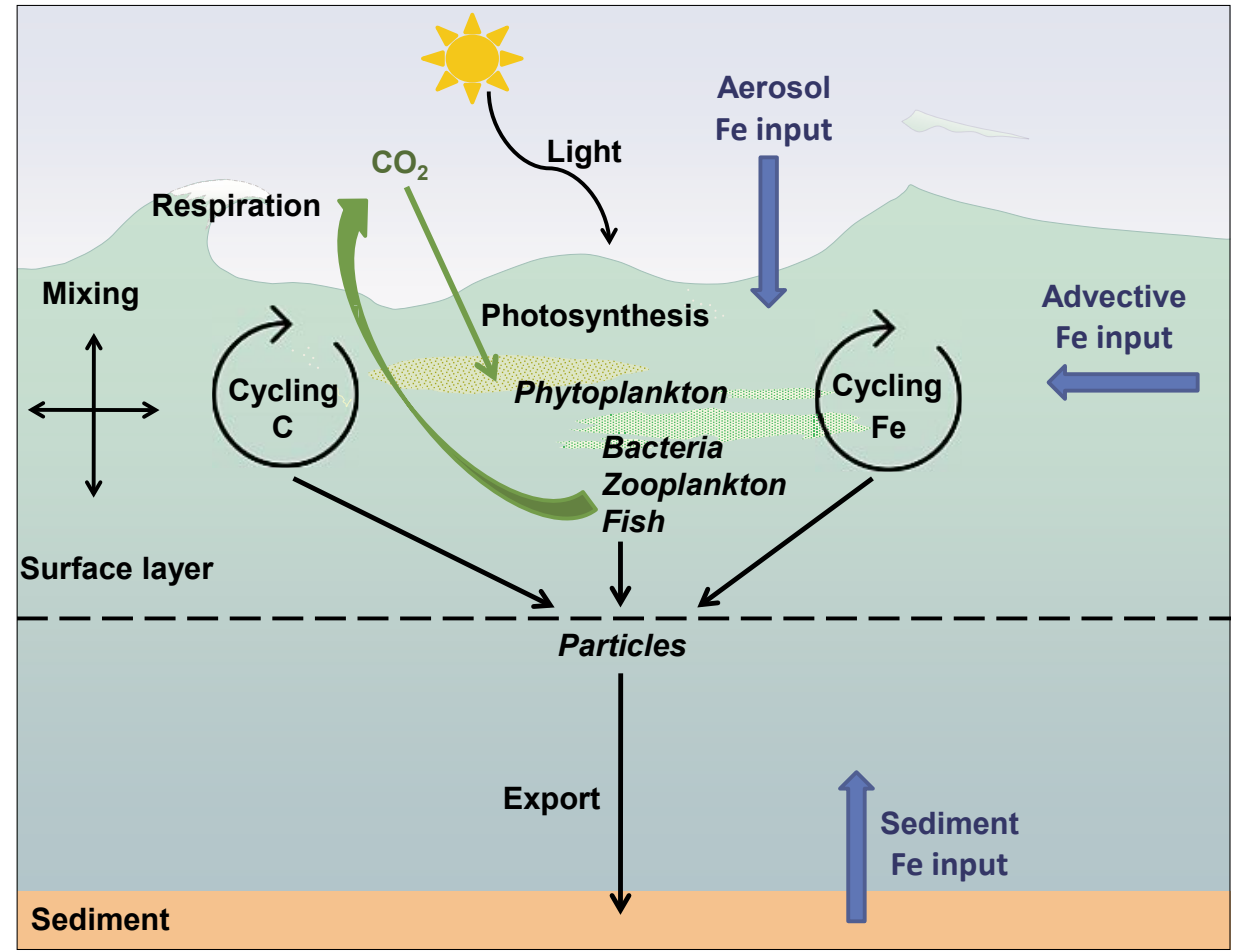

Fig. 1. Schematic of the links between iron $(\mathrm{Fe})$ and carbon $(\mathrm{C})$ cycling. Fe enters the oceans via a number of sources, i.e. aerosol input (dust, ash), advective processes (horizontal transport of coastal water masses, upwelling of sediments). Iron is a vital micronutrient for phytoplankton, which is involved in the process of photosynthesis. During photosynthesis phytoplankton fix atmospheric carbon dioxide $\left(\mathrm{CO}_{2}\right)$ into organic molecules. Thereby, transforming inorganic carbon into organic forms which are transferred through the entire marine food web. Some of the organic carbon is respired by phytoplankton and bacteria, recycled through the food web, and exported to the sediments. During these processes Fe will be recycled and exported. Processes are shown in bold black, $\mathrm{Fe}$ inputs in blue, carbon processes in green, and biological interactions in italics. Connections between the $\mathrm{Fe}$ and other elements (e.g. S, N, Si) cycling is not shown here for simplicity.

Iron is one of the most important micronutrients required for the growth and survival of phytoplankton. It is a cofactor of metaloenzymes and proteins, which are vital to metabolic processes such as photosynthesis, respiration, electron transport, nitrate reduction, and the detoxification of reactive oxygen species..$^{[1,4-7]}$ However, 
Fe limitation is widespread, affecting up to $50 \%$ of the world oceans, thereby impacting phytoplankton growth, primary productivity, community structure and biodiversity, and on a larger scale, ecosystem functioning and $\mathrm{CO}_{2}$ fixation. ${ }^{[6,8-10]} \mathrm{In}$ order to understand how aquatic systems function and increase our ability to predict the response of phytoplankton to changing conditions, it is therefore paramount to understand how $\mathrm{Fe}$ controls operate and where they are relevant. This review presents the complex relationship between Fe chemistry and the biology of surface waters to highlight the parameters defining the forms of $\mathrm{Fe}$ that are accessible for phytoplankton growth (or bioavailable).

\section{Iron Limitation in Aquatic Systems}

Numerous bottle incubations, as well as large-scale natural and artificial Fe fertilisation experiments, have confirmed John Martin's 'iron hypothesis' ${ }^{[11]}$ and demonstrated that the limitation of accessible $\mathrm{Fe}$ to sustain phytoplankton growth is the primary factor leading to low phytoplankton biomass in high nutrient, low chlorophyll (HNLC) regions. ${ }^{[8,12,13]}$ These include high latitude areas as well as important upwelling regions (e.g. ref. [14]). Fe limitation is not restricted to HNLC regions; areas of the Atlantic Ocean and the Coral Sea exhibit reduced primary productivity due to low nutrient concentrations, specifically nitrate $\left(\mathrm{NO}_{3}\right),{ }^{[15,16]}$ and are termed 'low nutrient, low chlorophyll (LNLC)' regions. Here Fe becomes a co-limiting factor due to its crucial role in nitrogen assimilation and $\mathrm{N}_{2}$ fixation. ${ }^{[15]}$ In these cases an input of $\mathrm{Fe}$ is unlikely to have the same effect as that seen in HNLC regions ${ }^{[17]}$ as the concentrations of other vital nutrients are too low to initiate growth.

Studies based on natural lake waters highlighted $\mathrm{Fe}$ deficiencies and limitations. ${ }^{[18-21]}$ It was demonstrated that $\mathrm{Fe}$ additions, using bioassay approaches, can stimulate phytoplankton growth and photosynthetic efficiency. ${ }^{[20]}$ A recent study conducted in Lake Geneva, showed similar results, with an increase of in vivo chlorophyll $a$ content in $\mathrm{Fe}$-enriched treatments. ${ }^{[22]}$ These results suggest that the phytoplankton communities of these lakes are at least $\mathrm{Fe}$ stressed, or even, Fe limited. ${ }^{[20,21]}$

\section{Iron Distribution in Aquatic Systems}

As it is the fourth most abundant element ${ }^{[23]}$ one would expect that Fe concentrations in aquatic systems would reflect this. However, the solubility of Fe is extremely low in contemporary well-oxy- genated water with $\mathrm{pH}>7^{[24-27]}$ resulting in low $\mathrm{Fe}$ concentrations in many natural waters.

The ubiquity of $\mathrm{Fe}$ in the environment makes accurate determination of this element in aquatic systems extremely difficult, particularly in open ocean samples. It is likely that sample contamination led to some inconsistencies in early measurements (pre 1970s) (see ref. [28] for a review). However, the development of 'clean' techniques for sampling, sample handling, and analysis has alleviated this issue somewhat.[21,28,29] The advancement of analysis techniques and improved sensitivity have also improved the accuracy of Fe measurements.

Since the 1990s numerous studies have measured dissolved iron $(\mathrm{dFe})$ in the ocean. In fact, large international efforts in the framework of the GEOTRACES program resulted in the release of $3 \mathrm{D} \mathrm{dFe}$ distributions of most ocean basins (eGEOTRACES, www.egeotraces.org).

In large areas of the oceans $\mathrm{dFe}$ concentrations in surface waters are extremely low, often $<1$ nM. ${ }^{[30-33]}$ Since the introduction of clean techniques data for lakes are still limited, ${ }^{[34]}$ recent studies highlighted that Fe concentrations are much lower than previously perceived. ${ }^{[20,35]}$ For the lakes studied (Laurentian Great Lakes, Lake Geneva and Lake Kinneret) dFe is reported to be present in concentrations ranging from 0.5 to $312 \mathrm{nM}$ (Table 1).[20,35-39]

The vertical and spatial distributions of $\mathrm{dFe}$ have similar patterns in large lakes and in the ocean. Vertical distributions are nutrient-like with low concentrations at the surface, as a result of biological uptake, and increasing concentrations with depth due to remineralisation, aggregation and settling, and sediment resuspension. ${ }^{[22,42-44]}$

Table 1. Range of measured dissolved and particulate $\mathrm{Fe}(\mathrm{III})$ in different lakes.

\begin{tabular}{|c|c|c|c|}
\hline & $\begin{array}{l}\text { Dissolved } \\
\text { Fe } \\
{[\mathrm{nM}]}\end{array}$ & \multicolumn{2}{|c|}{$\begin{array}{l}\text { Particulate Fe } \\
{[\mathrm{nM}]}\end{array}$} \\
\hline \multicolumn{4}{|l|}{ Lake Waters } \\
\hline Lake Erie & $\begin{array}{l}2.2-90 \\
3-34 \\
2.7-312 \\
1.2-5.7\end{array}$ & $\begin{array}{l}\text { na } \\
\text { na } \\
\text { na } \\
45.5-3643\end{array}$ & $\begin{array}{l}{[35]} \\
{[20]} \\
{[36]} \\
{[40]}\end{array}$ \\
\hline Lake Ontario & $\begin{array}{l}2.6-73 \\
0.5-26\end{array}$ & $\begin{array}{l}\text { na } \\
\text { na }\end{array}$ & $\begin{array}{l}{[35]} \\
{[35]}\end{array}$ \\
\hline Lake Superior & $\begin{array}{l}1.6-8.7 \\
0.6-27 \\
15 \\
1.3-75.8\end{array}$ & $\begin{array}{l}39.4-75.4 \\
\text { na } \\
\text { na } \\
\text { na }\end{array}$ & $\begin{array}{l}{[38]} \\
{[35]} \\
{[39]} \\
{[41]}\end{array}$ \\
\hline Lake Kinneret & $31-37$ & $86-379$ & [37] \\
\hline Lake Geneva & $2-30^{\mathrm{a}}$ & na & \\
\hline
\end{tabular}

aMoisset et al., unpublished data ${ }^{[22]}$
In the global ocean, average dFe concentrations vary from $0.07 \mathrm{nmol}$ at the surface to $0.76 \mathrm{nmol}$ at depth (Table 2). ${ }^{[44]}$ Fe seasonal variability exhibits a net decrease of $\mathrm{dFe}$ concentrations at the level of the deep layer chlorophyll $a$ maximum during spring to summer months and an increase due to winter mixing. This indicates that biological activities and mixing processes are important for Fe distribution. A spatial gradient of $\mathrm{dFe}$ in the epilimnion of lakes has been observed, from nearshore (dFe mean: $31.7 \mathrm{nM}$ ) to isolated areas (dFe mean: 1.5 $\mathrm{nM}$ ), showing a strong increase of dFe concentration along the coastline as a result of lake-edge sources. ${ }^{[20,35,41]}$ Elevated Fe concentrations are indeed generally found in near-shore waters, ${ }^{[64]}$ often in the range of 100-1000 times higher than that found in the open ocean. ${ }^{[6]}$ Despite a relatively high concentration of $\mathrm{Fe}$ in rivers, ${ }^{[64]}$ very little riverine Fe reaches the open ocean as most of it is removed by precipitation, coagulation, and sedimentary processes favoured by the increase of salinity in estuaries. [64]

\section{Sources of Iron}

Iron sources are numerous, and their relative importance to the observed $\mathrm{Fe}$ concentration varies regionally and seasonally. Fe reaches marine waters via atmospheric aerosols, ${ }^{[24,65-67]}$ riverine input, melting of sea ice, ${ }^{[68,69]}$ icebergs, ${ }^{[69]}$ glacial ice, ${ }^{[70,71]}$ continental margins, ${ }^{[72-74]}$ transport of hydrothermal $\mathrm{Fe}$ residuals, ${ }^{[75]}$ anoxic sediments, and recycling by organisms from viruses to whales. ${ }^{[43,76-84]}$

Four Fe sources dominate in lakes: (i) river inputs (e.g. fluvial influx and wastewaters), (ii) atmospheric inputs (e.g. precipitation and dust), (iii) sediment resus- 
Table 2. Range of measured dissolved and particulate Fe(III), Fe-binding organic ligand concentration, and measured stability constants with inorganic $\mathrm{Fe}\left(\log \mathrm{K}_{\mathrm{Fe}^{\prime}-\mathrm{L}}^{\prime}\right)$ in different ocean basins.

\begin{tabular}{|c|c|c|c|c|c|c|c|}
\hline & $\begin{array}{l}\text { Dissolved } \\
\text { Fe [nM] }\end{array}$ & $\begin{array}{l}\text { Particulate } \\
\text { Fe }[\mathbf{n M}]\end{array}$ & $\begin{array}{l}\text { [Ligand] } \\
{[\mathrm{nM}]}\end{array}$ & & $\log K_{F e^{\prime}-L}^{\prime}$ & & \\
\hline \multicolumn{8}{|l|}{ Sea Waters } \\
\hline Arctic & $1.0-3.2$ & na & na & & \multicolumn{2}{|l|}{ na } & [45] \\
\hline Subarctic Pacific & $\begin{array}{l}0.02-0.1 \\
0.6-0.8 \\
0.02\end{array}$ & $\begin{array}{l}\text { na } \\
\text { na } \\
>1.0\end{array}$ & $\begin{array}{l}\text { na } \\
\text { na } \\
0.5\end{array}$ & & \multicolumn{2}{|l|}{$\begin{array}{l}\text { na } \\
\text { na } \\
11.3-12.5\end{array}$} & $\begin{array}{l}{[46]} \\
{[47]} \\
{[48]}\end{array}$ \\
\hline North pacific & $\begin{array}{l}\text { na } \\
\text { na } \\
0.2 \\
0.7-0.8\end{array}$ & $\begin{array}{l}0.1-0.2 \\
0.1-0.3 \\
\text { na } \\
\text { na }\end{array}$ & $\begin{array}{l}\text { na } \\
\text { na } \\
\text { na } \\
\text { L1: } 0.4\end{array}$ & L2: 1.5 & \multicolumn{2}{|c|}{$\begin{array}{l}\text { na } \\
\text { na } \\
\text { na } \\
\text { L1: } 13.1 \quad \text { L2: } 11.5\end{array}$} & $\begin{array}{l}{[49]} \\
{[50]} \\
{[51]} \\
{[51]}\end{array}$ \\
\hline Equatorial Pacific & $\begin{array}{l}\leq 0.05 \\
0.05 \\
0.02-0.04\end{array}$ & $\begin{array}{l}\text { na } \\
\text { na } \\
0.1-0.5\end{array}$ & $\begin{array}{l}\text { na } \\
\text { na } \\
\mathbf{L 1}: 3.1\end{array}$ & L2: 1.9 & \multirow{2}{*}{\multicolumn{2}{|c|}{$\begin{array}{l}\text { na } \\
\text { na } \\
\text { L1: } 12.6 \quad \text { L2: } 11.8\end{array}$}} & $\begin{array}{l}{[52]} \\
{[53]} \\
{[54]}\end{array}$ \\
\hline Arabian Sea & $\begin{array}{l}0.5-2.4 \\
1.3-2.6\end{array}$ & $\begin{array}{l}\text { na } \\
\text { na }\end{array}$ & $\begin{array}{l}\text { na } \\
0.2-3.8\end{array}$ & & & & $\begin{array}{l}{[55]} \\
{[56]}\end{array}$ \\
\hline North Atlantic & $\begin{array}{l}1.8 \\
0.2 \\
0.4-0.7 \\
0.4 \pm 0.05\end{array}$ & $\begin{array}{l}\text { na } \\
\text { na } \\
\text { na } \\
\text { na }\end{array}$ & $\begin{array}{l}\text { na } \\
3.5-4.8 \\
0.5-0.6 \\
\text { L1: } 1.1 \pm 0.09\end{array}$ & L2: $2.1 \pm 0.002$ & \multicolumn{2}{|c|}{$\begin{array}{l}\text { na } \\
18.8-19.7 \\
\text { na } \\
\text { L1: } 13 \quad \text { L2: } 11.6\end{array}$} & $\begin{array}{l}{[57]} \\
{[58]} \\
{[59]} \\
{[59]}\end{array}$ \\
\hline South Atlantic & $0.05-0.3$ & na & na & & \multicolumn{2}{|l|}{ na } & [33] \\
\hline Southern Ocean & $\begin{array}{l}0.08 \pm 0.03 \\
0.05-0.5 \\
0.3 \pm 0.2 \\
0.06-0.09 \\
\text { na }\end{array}$ & $\begin{array}{l}\text { na } \\
\text { na } \\
\text { na } \\
\text { na } \\
0.5-0.9\end{array}$ & $\begin{array}{l}\mathrm{Na} \\
0.2-1.4 \\
0.7 \pm 0.2 \\
0.6-0.8 \\
\text { na }\end{array}$ & & \multicolumn{2}{|l|}{$\begin{array}{l}\text { na } \\
\text { na } \\
\text { na } \\
\text { na } \\
\text { na }\end{array}$} & $\begin{array}{l}{[60]} \\
{[32]} \\
{[32]} \\
{[61]} \\
{[62]}\end{array}$ \\
\hline Southern Ocean & $0.2-0.4$ & na & $0.8 \pm 0.20$ & & \multicolumn{2}{|l|}{$11.5 \pm 0.2$} & [63] \\
\hline
\end{tabular}

pension and (iv) reductive remobilization of Fe from the sediment. Those sources are mainly balanced with outflow and sedimentation processes. ${ }^{[37,85]}$ To date, only a few studies have measured Fe budgets in freshwater lakes. Measurement of high $\mathrm{dFe}$ concentration in river influx of Lake Kasumigaura (686-2910 nM) compared to lakewater (35-254 nM), suggest that riverine Fe was the major source in this lake. ${ }^{[86]}$ Similar observations were made in Lake Kinneret where the Jordan River appears to be the main source of $\mathrm{dFe}\left(6-13 \mu \mathrm{M}^{[37]}\right)$. The high contribution of fluvial inputs to $\mathrm{dFe}$ concentrations can be explained by the lakes' large watershed area. ${ }^{[37]}$ Indeed, $\mathrm{Fe}$ comes from the products of weathered rocks and soil around watersheds. ${ }^{[85]}$

Globally the largest input into the oceans comes from atmospheric dust deposition, ${ }^{[67]}$ although exceptions to this may be upwelling areas or coastal regions with large river inputs. ${ }^{[52]}$ It is estimated that $\sim 3$ times more $\mathrm{dFe}$ enters the oceans via atmospheric deposition than via rivers. ${ }^{67]}$

In HNLC regions and oligotrophic waters, the flux of upwelled Fe has been found to be significant, and in some cases, the dominant source. ${ }^{[64]}$ For example, it is estimated that the upward Fe flux is $\sim 10$ times and $>5$ times higher than that of the atmospheric contribution in the equatorial Pacific ${ }^{[52]}$ and in the Southern Ocean, ${ }^{[74]}$ respectively. As such, upwelled Fe represents the primary source of this element in Antarctic waters. ${ }^{[87]}$ In the subarctic Pacific however, atmospheric sources appear to be dominant ( $~ 10$ times greater than upwelled $\mathrm{Fe}) .[64,87]$

The Southern Ocean is the largest HNLC area where the lack of Fe limits the growth of phytoplankton. ${ }^{[88]}$ In Antarctic sea ice Fe can accumulate in concentrations one or two orders of magnitude higher than that of the underlying seawater (sea ice 2.6-26 $\mathrm{nM}^{[89]}$ ). Lannuzel et al. ${ }^{[68]}$ showed that, over a 10-day period, $70 \%$ of the accumulated Fe could be released to surface waters through brine drainage during sea ice melting, suggesting that sea ice may promote the onset of a spring phytoplankton bloom, or at the very least sustain an existing bloom in Polar waters. Similarly, localised enhanced chlorophyll $a$ has been observed in the vicinity of free drifting icebergs. ${ }^{[71,90]}$

The effect of Fe input on aquatic phytoplankton depends on the time-set of input, rate and duration, the phytoplankton community present and its Fe nutritive status. [91] Therefore, variability of $\mathrm{Fe}$ input may cause corresponding variations in atmospheric/ocean $\mathrm{CO}_{2}$ exchange fluxes, the $\mathrm{C}, \mathrm{N}$, and $\mathrm{Si}$ budgets, ${ }^{[92]}$ depending on the dominant phytoplankton species present.

If future climatic variations alter dust seasonal transport and deposition processes, we are likely to see corresponding changes in the atmospheric deposition. ${ }^{[65]}$ For example, predictions of a dryer Australia with increased storm events may lead to increased dust deposition in the Tasman Sea and Southern Ocean, a possible increase in bioavailable $\mathrm{Fe},{ }^{[93]}$ and changes in phytoplankton community structure. Due to increased industrial and human activities, atmospheric dusts are becoming richer in essential elements such as $\mathrm{N}$ and toxic elements such as $\mathrm{Pb}(e . g$., ref. [14]), leading to complex effects on phytoplankton dynamics in natural systems.

Several tracers can be used to identify Fe sources. For example, the primary source of aluminium (Al) is from atmospheric dust; therefore, the $\mathrm{Fe} / \mathrm{Al}$ ratio is an ideal measurement to identify atmospheric input versus continental margin inputs. ${ }^{[94,95]}$ Additionally, radium isotopes ( $\mathrm{Ra}$ ) can be used to identify sedimentary inputs and dispersal rates.[96] $\mathrm{Fe}$ isotopic signature is another promising technique sensitive to $\mathrm{Fe}$ redox and biological reactions. ${ }^{[97]}$ 
This method has been used successfully in palaeo-reconstructions of marine environments ${ }^{[98]}$ and studies of contemporary ocean waters reveal that many $\mathrm{Fe}$ sources have unique $\mathrm{Fe}$ isotopic signatures (e.g. desert soils $\delta^{56}$ total $\mathrm{Fe}\left(\mathrm{Fe}_{\mathrm{T}}\right) 0.04$ to $0.08 \%$, soluble $\mathrm{Fe} \sim 0.13 \%$ o, ${ }^{[99]}$ hydrothermal inputs -0.11 to $-0.77 \%$, ${ }^{[100,101]}$ continental shelf sediments -3.4 to $-2.7 \%$. $^{[102]}$ Therefore additional effort should be made to characterise these signatures in order to efficiently track Fe sources.

\section{Iron Chemistry in Aquatic Systems}

Iron is present in a variety of size fractions, operationally defined as dissolved and particulate. ${ }^{[64]}$ A significant fraction of $\mathrm{dFe}$ is in fact colloidal, likely both inorganic and organic colloids. ${ }^{[103-106]}$ The dissolved phase is therefore further split into soluble and colloidal. To complicate matters further the speciation of $\mathrm{Fe}$ is controlled by the redox state (Fe(II) or $\mathrm{Fe}(\mathrm{III})$ ), and complexation with a variety of organic ligands (Fig. 2). ${ }^{[40,83,107,108]}$

Iron chemical speciation has been studied using Competitive Ligand Exchange-Adsorptive Cathodic Stripping Voltammetry (CLE-ACSV) since 1994. ${ }^{[51,57]}$ The results indicate that $>99.9 \%$ of the $\mathrm{dFe}$ in seawater is bound to organic ligands.[109] The ambient Fe-binding ligands determined by this technique are typically described as ligand 'classes' which are operationally defined by the associated conditional stability constant $K_{F e L i}^{\text {cond }}$ measured. Ligand classes are denoted as $\mathrm{L}_{\mathrm{i}}$, where $\mathrm{i}=1$ for stronger ligand classes and $\mathrm{i}=$ 2,3 , etc., for progressively weaker ligand classes. Generally, speciation of Fe(III) is dominated by $\mathrm{L}_{1}\left(\mathrm{~K}_{\mathrm{FeL} 1}>10^{22} \mathrm{M}^{-1}\right)$ in the mixed layer and $\mathrm{L}_{2}\left(\mathrm{~K}_{\mathrm{FeL} 2} \approx 10^{21-22} \mathrm{M}^{-1}\right)$ in the deep ocean. ${ }^{[51]}$ Several Fe binding organic ligands have been identified in seawater. These include bacterially produced siderophores $\left(\mathrm{L}_{1}\right),{ }^{[107,110,111]}$ exopolymeric substances (EPS), which are released by most microorganisms $\left(\mathrm{L}_{1}\right.$ or $\left.\mathrm{L}_{2}\right),{ }^{[112,113]}$ porphyrin and saccharides, released via cell lysis and grazing $\left(\mathrm{L}_{2}\right),[108,114,115]$ and humic substances $\left(\mathrm{HS}, \mathrm{L}_{2}\right)$. $^{[116,117]}$ The role of these organic ligands has been recently reviewed elsewhere. ${ }^{[109,118,119]}$

Humic substances (HS) can make up a substantial percentage of the dissolved organic matter (DOM) pool in aquatic environments, with estimates ranging between 40 and $80 \%$ in freshwater, ${ }^{[120,121]}$ and between 10 and $50 \%$ in estuaries and coastal waters. ${ }^{[122]} \mathrm{HS}$ are less abundant in marine systems but can account for 5-25\% of the DOM pool even in remote ocean regions. ${ }^{[120]}$ Several studies conducted in coastal oceans, ${ }^{[16]}$ estuaries $^{[123]}$ and riv-

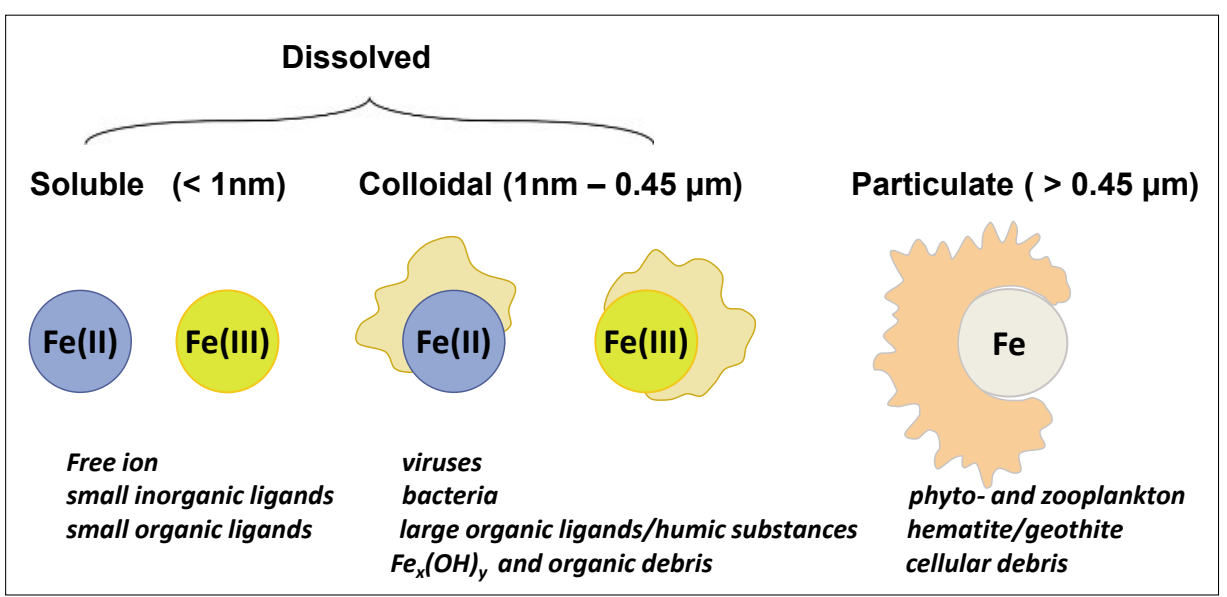

Fig. 2. The various size fractions, species, and associated biology and natural organic matter (NOM) of Fe that exist in marine waters. Iron size fractions are operationally defined as dissolved and particulate. The dissolved fraction is further split into soluble $(<1 \mathrm{~nm})$ and colloidal $(1 \mathrm{~nm}-$ $0.45 \mu \mathrm{m})$. Fe is present in the ocean as both $\mathrm{Fe}(\mathrm{III})$ and the reduced $\mathrm{Fe}(\mathrm{II})$ species, and occurs as free ions and, predominantly, associated with organic ligands and humic substances.

ers ${ }^{[86,124]}$ have demonstrated that the HS (fulvic acid, and to a lesser extent, humic acid) can account for the majority of the total ligand pool. To date, only one study has investigated the organic Fe speciation in lakes. ${ }^{[86]}$ Their results revealed that most of the $\mathrm{dFe}$ is largely organic and is primarily bound to fulvic acid.

Recent data suggested that EPS could represent a significant portion of the HS present in the open ocean with important consequences for phytoplankton growth. ${ }^{[125,126]}$ Carbohydrates are an important component of DOM as well as EPS. For example, the concentration of uronic acids are variable in both algal and bacterial EPS, ${ }^{[127,128]}$ but can account for between $20-50 \%$ of the polysaccharides produced by some marine bacteria. ${ }^{[129]}$ Saccharides can bind Fe, enhancing its reduction and solubility, and forming highly bioavailable $\mathrm{Fe}$ forms to marine phytoplankton. [112-114,119,130-132] Interestingly, high levels of $\mathrm{dFe}(0.2-14.4$ $\mathrm{nM})$ and EPS (2.8-2690 $\mu \mathrm{g}$ xanthan equivalent $\mathrm{L}^{-1}$ ), were measured in Antarctic sea ice compared to underlying seawater.[133] However EPS contain many other metals (toxic and essential) and macronutrients as well as many functional binding groups, so the mechanisms by which it associates with Fe, as well as its impact on phytoplankton, is not yet resolved. ${ }^{[125,126]}$

Organic complexation is extremely important for maintaining solubility[25,134-136] and controlling the bioavailability of $\mathrm{Fe}$ to bacterio- and phytoplankton. ${ }^{[108,109,112,135,137-139] \quad \text { Soluble }}$ complexed $\mathrm{Fe}$ is not scavenged but remains accessible in surface waters for prolonged periods. ${ }^{[140]}$ For example, in the presence of organic ligands the solubility $\mathrm{Fe}$ (III) is in the order of $0.2-0.6 \mathrm{nM}$ in surface waters, ${ }^{[26,136]}$ and reaches minimum values $(0.15-0.2 \mathrm{nM})$ at depths between 50 and $200 \mathrm{~m} \cdot{ }^{[136]}$ In the absence of organic complexation however, inorganic Fe(III) is highly insoluble ${ }^{[141]}$ and will rapidly hydrolyse and form colloidal Fe oxyhydroxides $^{[25,142]}$ resulting in the continual removal of $\mathrm{Fe}$ oxides from the surface ocean via scavenging and adsorption onto sinking particles. ${ }^{[143]}$

Generally the predominant form of Fe in seawater is the more thermodynamically stable $\mathrm{Fe}$ (III). ${ }^{[144]} \mathrm{Fe}(\mathrm{II})$ generally undergoes rapid oxidation in well-oxygenated surface waters, exhibiting a halflife of minutes at the normal $\mathrm{pH}$ of seawater $(\sim 8) .{ }^{[144,145]}$ However, factors such as low temperatures, and complexation with organic ligands have been shown to slow down the oxidation kinetics of $\mathrm{Fe}(\mathrm{II})$, and increase the half-life, in some cases to hours. ${ }^{[146-149]}$ In lake systems, the ratio $\mathrm{Fe}(\mathrm{II}) / \mathrm{Fe}_{\mathrm{T}}$ showed a day/night cycle with concentrations of $\mathrm{Fe}(\mathrm{II})$ below the detection limit during the night and up to $1 \mathrm{nM}$ near the surface during the day.[150] These low concentrations are associated with the rapid reoxidation of the $\mathrm{Fe}$ (III) species. An exception was observed in lake Kinneret ${ }^{[151]}$ where concentrations of $\mathrm{Fe}(\mathrm{II})$ ranging from $0.05 \mu \mathrm{M}$ to $0.15 \mu \mathrm{M}$ were measured during the year. It has been proved that these high values are due to both phytoplankton driven reduction of $\mathrm{Fe}(\mathrm{III})$ and the stabilization of $\mathrm{Fe}(\mathrm{II})$. $^{[37]}$

The reduction and oxidation of $\mathrm{Fe}$ can occur through a number of processes whether present as $\mathrm{Fe}(\mathrm{III})$ prime (Fe(III)') or $\mathrm{Fe}(\mathrm{II})$ prime ( $\left.\mathrm{Fe}(\mathrm{II})^{\prime}\right)$ (which are inorganic species), or as Fe(III) or (II)-ligand complexes (Fig. 3). These processes include direct mediation through the photochemical reduction of colloidal $\mathrm{Fe}^{[152]}$ or 
Fe(III)-organic ligand complexes, ${ }^{[107,153]}$ or direct biological reduction via biological ferrireductase. Indirect reduction pathways come from the production of the reductant superoxide via the photodegradation of natural organic matter $(\mathrm{NOM})^{[154-156]}$ or from microbial excretion products. ${ }^{[157]}$ Work by Garg et al. ${ }^{[154]}$ using the red tide algae Chattonella marina indicates that the production of superoxide plays a much larger role in Fe uptake when the Fe is bound to weak ligands than when it is bound to strong ligands. Light can influence not only the Fe but also the organic ligands themselves. Chromophores contained in HS are highly susceptible to photodegradation, ${ }^{[153]}$ however this is not the case for all organic ligands. Siderophores containing hydroxamate groups are photochemically stable whether free or bound to Fe. The siderophores containing catecholate groups photo-oxidise when free but are stable when bound to Fe. However, for those siderophores containing $\alpha$-hydroxy carboxylate groups the opposite is true. ${ }^{[153]}$ $\mathrm{Fe}$ redox processes are influenced by the Fe species and organic ligands present, and the chemical environment of the surrounding waters, with $\mathrm{Fe}$ (II) complexes often being weaker than $\mathrm{Fe}(\mathrm{III})$ complexes. ${ }^{[141]}$

\section{Iron Bioavailability}

Bioavailable $\mathrm{Fe}$ is the part of this element pool present in an aquatic system which is biologically accessible to microorganisms and can sustain their growth. Therefore, in Fe limited regions, bioavailability controls phytoplankton biomass and the species composition of the phytoplankton assemblage, which in turn influences the community food web. ${ }^{[12,158]}$ The complex and dynamic behaviour of Fe in surface waters, its speciation, and redox chemistry means that the parameters which control Fe bioavailability are still poorly understood.

The bioavailability of $\mathrm{Fe}$, is dependent on physical (diffusion ${ }^{[159]}$ ), biological (transport across cell membranes or uptake ${ }^{[141,160]}$ ), and chemical factors (dissociation kinetics of metal complexes and the various chemical forms of $\mathrm{Fe}^{[141,158,160]}$ ) both within the cell and in the environment immediately adjacent to the cell.[160] The rate of any of the steps (diffusion, uptake, or kinetic flux) has the potential to limit the efficiency of $\mathrm{Fe}$ assimilation. The importance of $\mathrm{Fe}$ kinetics in seawater was recently reviewed in Croot and Heller.[161] The rate of uptake is defined by a microorganism's Fe requirement, Fe transporters, and the concentration of free $\mathrm{Fe}$ and labile Fe. [141,160] The diffusive flux of Fe to the cell surface is determined by the size fraction of the Fe present (i.e. dissolved, colloi-

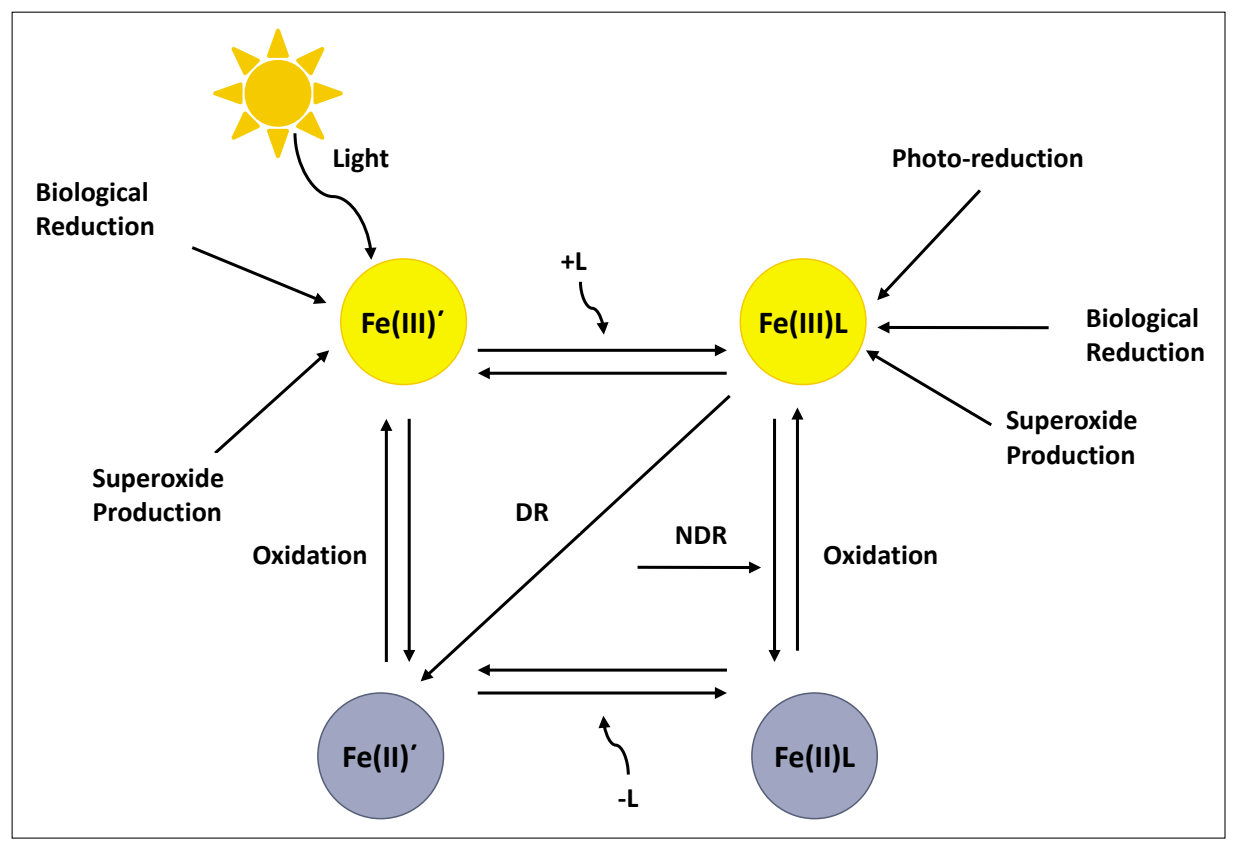

Fig. 3. Representation of the Fe redox cycle. Fe exists in the ocean mainly as Fe(III), either as inorganic $\mathrm{Fe}(\mathrm{III})^{\prime}$, or bound to organic ligands (Fe(III)L). Organically bound $\mathrm{Fe}(\mathrm{III})$ is the predominant form (>99\%). Both $\mathrm{Fe}(\mathrm{III})$ ' and $\mathrm{Fe}(\mathrm{III}) \mathrm{L}$ can be reduced by the action of sunlight (photo-reduction, production of superoxide by NOM), or by biological activity (biological reduction, i.e. ferrireductase, and biological production of superoxide). Fe reduction can induce the dissociation of $\mathrm{Fe}($ (II) $L$ (e.g. dissociative reduction, DR), or generate $F e(॥) L$ (e.g. non-dissociative reduction, NDR). The $\mathrm{Fe}(I) \mathrm{L}$ complexes are generally weaker than $\mathrm{Fe}(\mathrm{II}) \mathrm{L}$ complexes and will easily dissociate to $\mathrm{Fe}(\mathrm{II}) '$. In oxygenated water the $\mathrm{Fe}\left({ }^{\prime \prime}\right)^{\prime}$ is then rapidly reoxidised by $\mathrm{O}_{2}$ to $\mathrm{Fe}(\mathrm{II})$ '.

dal, particulate $\left.{ }^{[160,162]}\right)$, the shape and size of the organism, and their motility. ${ }^{[163,164]}$ If the uptake rate is faster than the rate at which the $\mathrm{Fe}$ diffuses at the cell surface then diffusion limitation will occur.[140] The kinetic flux to the cell surface is determined by the stability and binding affinity of Fe complexes and the rate at which dissociation of these complexes occurs. ${ }^{[141,160]}$ Again, the strength of the Fe complex and therefore the rate of its dissociation can limit uptake rate. ${ }^{[141]}$

Iron solubility measurements have often been used to infer bioavailability; but the two terms are not interchangeable. Typically it is assumed that dissolved $\mathrm{Fe}(\mathrm{III})$ ' and $\mathrm{Fe}(\mathrm{II})^{\prime}$, and some dissolved organically complexed Fe(III) are bioavailable. ${ }^{[108,165-167]}$ However, the Fe requirement and uptake strategies of planktonic communities differ considerably ${ }^{[6,166]}$ so a pool of $\mathrm{Fe}$ that is bioavailable to one species will not necessarily be available to another. ${ }^{[113]}$ For example, dFe(II) is not always bioavailable to diatom species ${ }^{[167-169]}$ and organically complexed Fe is not universally available to both bacterioplankton and eukaryotic phytoplankton. ${ }^{[108,110]}$

Iron biological requirement for growth defines the control that $\mathrm{Fe}$ bioavailability exerts on the structure of the phytoplankton community, and the threshold of the bioavailable Fe concentration under which phytoplankton induce high affinity transporters to increase Fe uptake rates. ${ }^{[170]}$ The different Fe biological transporters used by phytoplankton were recently reviewed in Morrissey and Bowler.[171] Coastal phytoplankton usually have a higher Fe requirement for growth than oceanic species. ${ }^{[6]}$ In addition, the $\mathrm{Fe}$ requirement seems to be related to the phytoplankton aspect ratio (ratio of cellular volume to surface).[114,172] Elemental stoichiometric ratio can also be used to infer biological requirement for growth or Fe limitation. ${ }^{[119,173]}$ To date, little is known on freshwater eukaryotic phytoplankton Fe requirement.

In some regions of the world ocean the concentration of inorganic Fe is sufficient to sustain phytoplankton growth. However, in other areas, such as HNLC regions, the reported inorganic Fe concentrations $(<2$ $\mathrm{pM})$ are not. In these regions the production of Fe binding organic ligands and the rate of the kinetic flux (i.e. mediated by photoreactions or biological transformation) will be important factors in determining the bioavailable Fe pool, ${ }^{[137,160]}$ particularly to phytoplankton with high biological Fe requirement.

Concentration of bioavailable $\mathrm{Fe}$ in seawater and freshwater samples can be inferred using different methodologies. One is by using bioassays based on whole-cell Fe-dependent cyanobacterial bioreporters. The bioreporter BMB04 is a genetically modified strain of Synechococcus sp. (strain PCC 7002) constructed by introduction of the Fe-responsive gene isi $\mathrm{AB}$ fused 
to the lux $\mathrm{AB}$ genes that produce luminescence in response to environmental $\mathrm{Fe}$ availability in seawater. ${ }^{[174]}$ Cellular bioluminiscence increases with Fe limitation and it needs to be carefully calibrated in artificial seawater with varying $\mathrm{dFe}$ concentrations and a constant concentration of an appropriate Fe binding organic ligand. [175] Other cyanobacterial bioreporters have been optimised to sense Fe bioavailability[176] and other macronutrients (nitrate and phosphate) in freshwater environments. ${ }^{[177,178]}$ Because bioreporters' signal is based on gene expression, it includes metabolic uptake and homeostasis costs.[119] The other method typically used to infer Fe bioavailability is based on bioaccumulation experiments to calculate $\mathrm{Fe}$ uptake rate. Bioaccumulation experiments measure intracellular $\mathrm{Fe}$ concentrations after incubation of the microorganisms of interest in the medium enriched with the radioisotope ${ }^{55} \mathrm{Fe}$ or ${ }^{59} \mathrm{Fe} .{ }^{[179]}$ This methodology offers the advantage that it can be used with monoclonal cultures or natural phytoplankton communities typical to the study area and incubated under in situ environmental conditions. Because cyanobacterial bioreporters rely on a different uptake pathway than eukaryotic phytoplankton, ${ }^{180]}$ both methodologies should be used in combination in order to strengthen determination of Fe bioavailability to natural phytoplankton. ${ }^{[119]}$

It is estimated that $\sim 80 \%$ of the $\mathrm{Fe}$ present in phytoplankton cells is involved in the photosynthetic machinery. ${ }^{[181]}$ Under $\mathrm{Fe}$ deficient conditions, phytoplankton modify their photosynthetic machinery by reducing the concentration of Fe-rich cellular components ${ }^{[182,183]}$ and modifying the light-harvesting systems. ${ }^{[184]}$ These changes cause a decrease of the photochemical efficiency in phytoplankton photosynthesis and growth rate. ${ }^{[185]}$ For instance, the growth of cyanobacteria Synechococcus sp. (strain PCC 7002) was characterized in artificial seawater under different concentrations of $p \mathrm{Fe}$ (equivalent to $-\log _{10}$ $[\mathrm{Fe}(\mathrm{III})])$. The concentration of Fe required to achieve a growth rate half of maximal $\left(\mathrm{K}_{\mathrm{m}}\right.$ ) was $22.7 \pm 0.6 \mathrm{pFe}$ (Michaelis-Menten fit $\mathrm{R}^{2}=0.9$; $\left.\mathrm{P}<0.0001\right)$. In line with this, the Fv/Fm (quantum yield of fluorescence) decreased from $0.4 \pm 0.014$ at $19.7 p \mathrm{Fe}$ to $0.2 \pm 0.02$ at $22.7 p \mathrm{Fe}$, which also highlights the limited ability of this microorganism to maintain growth under low Fe conditions. Therefore, the assessment of photosynthetic parameters also constitutes a meaningful tool to investigate the nutritional status of marine and freshwater natural phytoplankton communities, ${ }^{[186-188]}$ including $\mathrm{Fe}$ limitation in high nutrient low chlorophyll areas.

\section{Looking Towards the Future}

Despite numerous studies, a picture of the complex and dynamic relationship between $\mathrm{Fe}$ chemistry and the biology of surface waters is only just emerging. Determining what controls the bioavailability of Fe to phytoplankton is one of the main challenges in understanding how $\mathrm{Fe}$ limits oceanic primary productivity and biodiversity. Fe cycling is influenced by both its chemistry and biology; it is a balance between input, biological uptake and recycling, and Fe sedimentation (Fig. 1). Despite the knowledge that $>99.9 \%$ of $\mathrm{dFe}$ is bound to organic ligands, ${ }^{[109]}$ these compounds have been poorly characterised and literature regarding their environmental role on Fe cycling, and the role of aquatic microorganisms and viruses in the production and recycling of $\mathrm{Fe}$ binding organic ligands, is scarce. ${ }^{[119,189]}$

Through the production of organic material, such as siderophores, EPS and cell lysis material (e.g. heme), the microorganisms themselves are clearly exerting a feedback effect on Fe chemistry, ${ }^{[108,190]}$ although currently the role of the mixture of these products in $\mathrm{Fe}$ biogeochemistry is not fully resolved. Recent progress has been made on the identification of siderophores and hemes in natural waters. ${ }^{[109]}$ It is likely that the organic complexation of Fe to a yet poorly defined range of ligands exerts the largest influence on $\mathrm{Fe}$ bioavailability. However, progress needs to be made on their composition and identification in order to establish their relative importance in each aquatic region. This will move towards a better understanding of how Fe chemistry affects Fe limitation and co-limitation observed in both HNLC and LNLC regions. Similarly, the nature of organic ligands present in lakes needs further attention.

Due to differences in Fe biological requirements and uptake pathways, it is then expected that for a given Fe chemistry, the pool of bioavailable Fe will differ between species. ${ }^{[118,173,191]}$ As such further process studies complemented by large scale mapping exercises are required to better understand how Fe chemistry constrains phytoplankton biodiversity and productivity in different aquatic systems and regions. The measure of Fe bioavailability is currently suffering from a lack of standardisation, and tools that are able to rapidly measure Fe bioavailability are urgently needed. Such an approach is required to allow inter-laboratory efforts to map, in a quantitatively comparable manner, the extent of $\mathrm{Fe}$ limitation in aquatic systems. Possibly due to our limited understanding of the complex causality of the numerous Fe subcellular responses, it is still unclear whether a direct measurement (e.g. bioreporter, marker gene) or an indirect measurement (yet undefined chemical proxy, photobiology) of bioavailability is to be preferred.

Identification of the main regional $\mathrm{Fe}$ source is also critical to understanding its relationship to bioavailability, as this affects the retention time and chemical reactivity of $\mathrm{Fe}$ in the euphotic zone. Different sources may be more bioavailable than others but this will also be dependent on Fe speciation (and therefore its stability), the size fraction, and mode of supply to the upper ocean. Efforts in measuring their impact for aquatic chemistry and biology as well as the development of chemical tracers need to be maintained.

One of the most noticeable changes predicted in water chemistry is acidification. The fate of Fe limitation in acidifying oceans and lakes still remains unclear as $\mathrm{Fe}$ will become more soluble at lowered $\mathrm{pH}$, but will be more strongly bound to organic ligands. ${ }^{[192]}$ How a changing environment will alter the nature of biologically produced organic ligands, the rate of production and complexation, and essentially the bioavailability of Fe are largely unknown. Whether these alterations will be positive or negative, they will certainly affect phytoplankton productivity and biodiversity. Changes in the composition of phytoplankton communities have the potential to alter ecological interactions and functioning, thereby creating indirect effects throughout entire marine food webs. Only by improving our knowledge of these parameters will we be able to (i) understand the dynamic of Fe limited aquatic regions, (ii) improve existing biogeochemical models to accurately predict carbon fixation; and (iii) develop sustainable strategies for ocean resources.

\section{Acknowledgements}

We gratefully thank the Swiss National Science Foundation (Professor Fellowship project no PP00P2_138955), the Australian Research Council (ARC discovery project no. DP1092892) and the UTS Plant Functional Biology and Climate Change Cluster for funding. We thank Professors David Waite, Peter Ralph, Martina Doblin and William Gladstone for their input on earlier versions of this manuscript.

Received: September 22, 2014

[1] P. G. Falkowski, R. T. Barber, V. Smetacek, Science 1998, 281, 200.

[2] P. G. Falkowski, Photosynth. Res. 1994, 39, 235.

[3] C. E. Williamson, J. E. Saros, W. F. Vincent, J. P. Smol, Limnol. Oceanogr. 2009, 54, 2273.

[4] F. M. M. Morel, N. M. Price, Science 2003, 300, 944.

[5] W. G. Sunda, IUPAC Ser Anal. Phys. Chem. Environ. Syst. 2001, 7, 41.

[6] W. G. Sunda, S. A. Huntsman, Mar. Chem. 1995, 50, 189.

[7] F. M. M. Morel, R. J. M. Hudson, N. M. Price, Limnol. Oceanogr. 1991, 36, 1742. 
[8] P. W. Boyd, T. Jickells, C. S. Law, S. Blain, E. A. Boyle, K. O. Buesseler, K. H. Coale, J. J. Cullen, H. J. W. de Baar, M. Follows, M. Harvey, C. Lancelot, M. Levasseur, N. P. J. Owens, R. Pollard, R. B. Rivkin, J. Sarmiento, V. Schoemann, V. Smetacek, S. Takeda, A. Tsuda, S. Turner, A. J. Watson, Science 2007, 315,612 .

[9] H. J. W. de Baar, J. La Roche. in 'Marine Science Frontiers for Europe', Ed. G. Wefer, F. Lamy, F. Mantoura, Springer, Berlin, 2003, p. 79.

[10] N. M. Price, B. A. Ahner, F. M. M. Morel, Limnol. Oceanogr. 1994, 39, 520.

[11] J. H. Martin, S. E. Fitzwater, Nature 1988, 331, 341.

[12] B. Ellwood, Nat. Geosci. 2010, 3, 675.

[13] H. J. W. de Baar, P. W. Boyd, K. H. Coale, M. R. Landry, A. Tsuda, P. Assmy, D. C. E. Bakker, Y. Bozec, R. T. Barber, M. A. Brzezinski, K. O. Buesseler, M. Boye, P. L. Croot, F. Gervais, M. Y. Gorbunov, P. J. Harrison, W. T. Hiscock, P. Laan, C. Lancelot, C. S. Law, M. Levasseur, A. Marchetti, F. J. Millero, J. Nishioka, Y. Nojiri, T. van Oijen, U. Riebesell, M. J. A. Rijkenberg, H. Saito, S. Takeda, K. R. Timmermans, M. J. W. Veldhuis, A. M. Waite, C.-S. Wong, J. Geophys. Res.: Oceans 2005, 110, C09S16/1.

[14] C. M. Moore, M. M. Mills, K. R. Arrigo, I. Berman-Frank, L. Bopp, P. W. Boyd, E. D. Galbraith, R. J. Geider, C. Guieu, S. L. Jaccard, T. D. Jickells, J. La Roche, T. M. Lenton, N. M. Mahowald, E. Maranon, I. Marinov, J. K. Moore, T. Nakatsuka, A. Oschlies, M. A. Saito, T. F. Thingstad, A. Tsuda, O. Ulloa, Nat. Geosci. 2013, 6, 701.

[15] C. M. Moore, M. M. Mills, E. P. Achterberg, R. J. Geider, J. LaRoche, M. I. Lucas, E. L. McDonagh, X. Pan, A. J. Poulton, M. J. A. Rijkenberg, D. J. Suggett, S. J. Ussher, E. M. S. Woodward, Nat. Geosci. 2009, 2, 867.

[16] C. S. Law, National Institute of Water \& Atmospheric Research (NIWA), New Zealand, personal communication.

[17] S. Duggen, N. Olgun, P. Croot, L. Hoffmann, H. Dietze, P. Delmelle, C. Teschner, Biogeosciences 2010, 7, 827.

[18] C. K. Lin, C. L. Schelske, Can. J. Fish. Aquat. Sci. 1981, 38, 1.

[19] P. Hyenstrand, E. Rydin, M. Gunnerhed, J. Plankton Res. 2000, 22, 1113.

[20] M. R. Twiss, J. C. Auclair, M. N. Charlton, Can. J. Fish. Aquat. Sci. 2000, 57, 870.

[21] R. W. Sterner, T. M. Smutka, R. M. L. McKay, X. M. Qin, E. T. Brown, R. M. Sherrell, Limnol. Oceanogr. 2004, 49, 495.

[22] S. A. M. Moisset et al., unpublished data.

[23] S. R. Taylor, Geochim. Cosmochim. Acta 1964, $28,1273$.

[24] T. D. Jickells, Z. S. An, K. K. Andersen, A. R. Baker, G. Bergametti, N. Brooks, J. J. Cao, P. W. Boyd, R. A. Duce, K. A. Hunter, H. Kawahata, N. Kubilay, J. laRoche, P. S. Liss, N. Mahowald, J. M. Prospero, A. J. Ridgwell, I. Tegen, R. Torres, Science 2005, 308, 67.

[25] X. Liu, F. J. Millero, Mar. Chem. 2002, 77, 43.

[26] F. J. Millero, Earth Planet. Sci. Lett. 1998, 154, 323.

[27] W. Stumm, J. Morgan in 'Aquatic Chemistry: chemical equilibria and rates in natural water', Ed. John Wiley \& Sons, New York, 1996.

[28] A. R. Bowie, M. T. Maldonado, in 'Practical guidelines for the analysis of seawater', Ed. O. Wurl, CRC Press, 2009.

[29] G. Cutter, P. Andersson, L. Codispoti, P. Croot, R. François, M. C. Lohan, H. Obata, M. R. van der Loeff, 'Sampling and Sample-handling Protocols for GEOTRACES Cruises', 2010.

[30] P. Parekh, M. J. Follows, E. Boyle, Global Biogeochem. Cycles 2004, 18

[31] H. J. W. de Baar, J. T. M. de Jong, in 'The biogeochemistry of iron in seawater', Ed. D. R.
Turner, K. A. Hunter, John Wiley \& Sons, UK, 2001, p. 123.

[32] M. Boye, C. M. G. Van den Berg, J. T. M. De Jong, H. Leach, P. Croot, H. J. W. De Baar, Deep Sea Res., Part I 2001, 48, 1477.

[33] J. T. M. de Jong, J. den Das, U. Bathmann, M. H. C. Stoll, G. Kattner, R. F. Nolting, H. J. W. de Baar, Anal. Chim. Acta 1998, 377, 113.

[34] R. M. L. McKay, G. S. Bullerjahn, D. Porta, E. T. Brown, R. M. Sherrell, T. M. Smutka, R. W. Sterner, M. R. Twiss, S. W. Wilhelm, Aquat. Ecosyst. Health Manage 2004, 7, 475.

[35] J. O. Nriagu, G. Lawson, H. K. T. Wong, V. Cheam, Environ. Sci. Technol. 1996, 30, 178.

[36] D. Porta, G. S. Bullerjahn, M. R. Twiss, S. W. Wilhelm, L. Poorvin, R. M. L. McKay, J. Great Lakes Res. 2005, 31, 180.

[37] Y. Shaked, Y. Erel, A. Sukenik, Geochim. Cosmochim. Acta 2004, 68, 1439.

[38] C. Hassler, S. M. Havens, G. S. Bullerjahn, R. M. L. McKay, M. R. Twiss, Limnol. Oceanogr. 2009, 54, 987.

[39] M. P. Field, R. M. Sherrell, J. Anal. At. Spectrom. 2003, 18, 254.

[40] S. M. Havens, C. S. Hassler, R. L. North, S. J. Guildford, G. Silsbe, S. W. Wilhelm, M. R. Twiss, Can. J. Fish. Aquat. Sci. 2012, 69, 369.

[41] R. M. L. McKay, D. Porta, G. S. Bullerjahn, M. M. D. Al-Rshaidat, J. A. Klimowicz, R. W. Sterner, T. M. Smutka, E. T. Brown, R. M. Sherrell, J. Plankton Res. 2005, 27, 1033.

[42] J. M. Vraspir, A. Butler, Annu. Rev. Marine Sci. 2009, 1,43 .

[43] R. M. L. McKay, S. W. Wilhelm, J. Hall, D. A. Hutchins, M. M. D. Al-Rshaidat, C. E. Mioni, S. Pickmere, D. Porta, P. W. Boyd, Global Biogeochem. Cycles 2005, 19.

[44] K. S. Johnson, R. M. Gordon, K. H. Coale, Mar. Chem. 1997, 57, 181.

[45] Y. Nakayama, S. Fujita, K. Kuma, K. Shimada, J. Geophys. Res.: Oceans 2011, 116.

[46] J. H. Martin, R. M. Gordon, Deep Sea Res., Part I 1988, 35, 177.

[47] J. H. Martin, R. M. Gordon, S. Fitzwater, W. W. Broenkow, Deep Sea Res., Part I 1989, 36, 649.

[48] Y. Kondo, S. Takeda, J. Nishioka, H. Obata, K. Furuya, W. K. Johnson, C. S. Wong, Geophys. Res. Lett. 2008, 35

[49] K. W. Bruland, K. J. Orians, J. P. Cowen, Geochim. Cosmochim. Acta 1994, 58, 3171.

[50] K. S. Johnson, R. M. Gordon, K. H. Coale, Mar. Chem. 1997, 57, 137.

[51] E. L. Rue, K. W. Bruland, Mar. Chem. 1995, 50, 117.

[52] K. H. Coale, S. E. Fitzwater, R. M. Gordon, K. S. Johnson, R. T. Barber, Nature 1996, 379, 621.

[53] R. M. Gordon, K. H. Coale, K. S. Johnson, Limnol. Oceanogr. 1997, 42, 419.

[54] E. L. Rue, K. W. Bruland, Limnol. Oceanogr. 1997, 42, 901.

[55] C. I. Measures, S. Vink, Deep Sea Res., Part II 1999, 46, 1597

[56] A. E. Witter, B. L. Lewis, G. W. Luther, III, Deep Sea Res., Part II 2000, 47, 1517.

[57] M. Gledhill, C. M. G. van den Berg, Mar. Chem. 1994, 47, 41 .

[58] J.Wu, G.W.Luther, III, Mar. Chem. 1995, 50, 159.

[59] J. T. Cullen, B. A. Bergquist, J. W. Moffett, Mar. Chem. 2006, 98, 295.

[60] P. W. Boyd, A. J. Watson, C. S. Law, E. R. Abraham, T. Trull, R. Murdoch, D. C. E. Bakker, A. R. Bowie, K. O. Buesseler, H. Chang, M. Charette, P. Croot, K. Downing, R. Frew, M. Gall, M. Hadfield, J. Hall, M. Harvey, G. Jameson, J. LaRoche, M. Liddicoat, R. Ling, M. T. Maldonado, R. M. McKay, S. Nodder, S. Pickmere, R. Pridmore, S. Rintoul, K. Safi, P. Sutton, R. Strzepek, K. Tanneberger, S. Turner, A. Waite, J. Zeldis, Nature 2000, 407, 695.

[61] M. Boye, J. Nishioka, P. L. Croot, P. Laan, K. R. Timmermans, H. J. W. de Baar, Mar. Chem. 2005, 96, 257.
[62] R. D. Frew, D. A. Hutchins, S. Nodder, S. Sanudo-Wilhelmy, A. Tovar-Sanchez, K Leblanc, C. E. Hare, P. W. Boyd, Global Biogeochem. Cycles 2006, 20.

[63] E. Ibisanmi, S. G. Sander, P. W. Boyd, A. R. Bowie, K. A. Hunter, Deep Sea Res., Part II 2011, 58, 2113.

[64] N. M. Price, F. M. M. Morel, Met. Ions Biol. Syst. 1998, 35, 1.

[65] N. M. Mahowald, A. R. Baker, G. Bergametti, N. Brooks, R. A. Duce, T. D. Jickells, N. Kubilay, J. M. Prospero, I. Tegen, Global Biogeochem. Cycles 2005, 19.

[66] T. D. Jickells, L. J. Spokes, in 'The biogeochemistry of iron in seawater', Ed. D. R. Turner, K. A. Hunter, John Wiley \& Sons, UK, 2001, p. 85.

[67] R. A. Duce, N. W. Tindale, Limnol. Oceanogr. 1991, 36, 1715

[68] D. Lannuzel, V. Schoemann, J. de Jong, L. Chou, B. Delille, S. Becquevort, J. L. Tison, Mar. Chem. 2008, 108, 85.

[69] B. M. Loscher, H. J. W. DeBaar, J. T. M. DeJong, C. Veth, F. Dehairs, Deep Sea Res., Part II 1997, 44, 143.

[70] R. Raiswell, L. G. Benning, M. Tranter, S. Tulaczyk, Geochem. Trans. 2008, 9.

[71] R. Raiswell, M. Tranter, L. G. Benning, M. Siegert, R. De'ath, P. Huybrechts, T. Payne, Geochim. Cosmochim. Acta 2006, 70, 2765.

[72] P. J. Lam, J. K. B. Bishop, C. C. Henning, M. A. Marcus, G. A. Waychunas, I. Y. Fung, Global Biogeochem. Cycles 2006, 20.

[73] K. S. Johnson, F. P. Chavez, G. E. Friederich, Nature 1999, 398, 697.

[74] H. J. W. de Baar, J. T. M. de Jong, D. C. E. Bakker, B. M. Loscher, C. Veth, U. Bathmann, V. Smetacek, Nature 1995, 373, 412.

[75] J. Wu, M. L. Wells, R. Rember, Geochim. Cosmochim. Acta 2011, 75, 460 .

[76] S. Nicol, A. Bowie, S. Jarman, D. Lannuzel, K. M. Meiners, P. van der Merwe, Fish and Fisheries 2010, 11, 203.

[77] T. J. Lavery, B. Roudnew, P. Gill, J. Seymour, L. Seuront, G. Johnson, J. G. Mitchell, V. Smetacek, Proc. R. Soc. B 2010, 277, 3527.

[78] V. Smetacek, in 'The Impact of Global Warming on Polar Ecosystems', Ed. C. Duarte, Spain, 2008, p. 46.

[79] R. F. Strzepek, M. T. Maldonado, J. L. Higgins, J. Hall, K. Safi, S. W. Wilhelm, P. W. Boyd, Global Biogeochem. Cycles 2005, 19.

[80] L. Poorvin, J. M. Rinta-Kanto, D. A. Hutchins, S. W. Wilhelm, Limnol. Oceanogr. 2004, 49, 1734.

[81] S. W. Wilhelm, C. A. Suttle, Bioscience 1999, 49, 781 .

[82] R. Maranger, D. F. Bird, N. M. Price, Nature 1998, 396, 248

[83] K. Barbeau, J. W. Moffett, D. A. Caron, P. L. Croot, D. L. Erdner, Nature 1996, 380, 61.

[84] K. S. Johnson, K. H. Coale, V. A. Elrod, N. W. Tindale, Mar. Chem. 1994, 46, 319.

[85] W. Xing, G. Liu, Fresenius Environ. Bull. 2011, 20, 1339.

[86] T. Nagai, A. Imai, K. Matsushige, K. Yokoi, T. Fukushima, Water. Res. 2007, 41, 775.

[87] A. J. Watson, in 'The biogeochemistry of iron in seawater', Ed. D. R. Turner, K. A. Hunter, John Wiley \& Sons, UK, 2001, p. 291.

[88] J. H. Martin, Paleoceanography 1990, 5, 1.

[89] D. Lannuzel, V. Schoemann, J. de Jong, J.-L. Tison, L. Chou, Mar. Chem. 2007, 106, 18

[90] K. L. Smith, B. H. Robison, J. J. Helly, R. S. Kaufmann, H. A. Ruhl, T. J. Shaw, B. S. Twining, M. Vernet, Science 2007, 317, 478.

[91] R. A. Cropp, A. J. Gabric, M. Levasseur, G. H. McTainsh, A. Bowie, C. S. Hassler, C. S. Law, H. McGowan, N. Tindale, R. Viscarra Rossel, $J$. Mar. Syst. 2013, 117-118, 43.

[92] M. Veldhuis, H. J. W. de Baar, J. Sea Res. 2005, 53,1 . 
[93] A. Hodbay, E. S. Poloczanska, R. J. Matear, 'Report of the Australian Greenhouse Office', 2008.

[94] J. Tria, E. C. V. Butler, P. R. Haddad, A. R. Bowie, Anal. Chim. Acta 2007, 588, 153.

[95] C. I. Measures, E. T. Brown, in 'The impact of African Dust across the Mediterranean', Ed. S. Guerzoni, R. Chester, 1997, p. 389.

[96] M. A. Charette, M. E. Gonneea, P. J. Morris, P. Statham, G. Fones, H. Planquette, I. Salter, A. N. Garabato, Deep Sea Res., Part II 2007, $54,1989$.

[97] J. T. M. De Jong, V. Schoemann, D. Lannuzel, J. L. Tison, N. Mattielli, Geochim. Cosmochim. Acta 2008, 72, A209.

[98] O. J. Rouxel, A. Bekker, K. J. Edwards, Science 2005, 307, 1088 .

[99] M. Waeles, A. R. Baker, T. Jickells, J. Hoogewerff, Environ. Chem. 2007, 4, 233.

[100] O. Rouxel, W. C. Shanks, W. Bach, K. J Edwards, Chem. Geol. 2008, 252, 214.

[101] M. Sharma, M. Polizzotto, A. D. Anbar, Earth Planet. Sci. Lett. 2001, 194, 39.

[102] S. Severmann, J. McManus, W. M. Berelson, D. E. Hammond, Geochim. Cosmochim. Acta 2010, 74, 3984.

[103] M. Boye, J. Nishioka, P. Croot, P. Laan, K. R. Timmermans, V. H. Strass, S. Takeda, H. J. W. de Baar, Mar. Chem. 2010, 122, 20.

[104] B. A. Bergquist, J. Wu, E. A. Boyle, Geochim. Cosmochim. Acta 2007, 71, 2960.

[105] M. Chen, R. C. H. Dei, W.-X. Wang, L. Guo, Mar. Chem. 2003, 81, 177.

[106] M. L. Wells, Nature 1998, 391, 530.

[107] K. Barbeau, E. L. Rue, K. W. Bruland, A. Butler, Nature 2001, 413, 409.

[108] D. A. Hutchins, A. E. Witter, A. Butler, G. W. Luther, Nature 1999, 400, 858.

[109] M. Gledhill, K. N. Buck, Front. Microb. 2012, 3.

[110] M. T. Maldonado, R. F. Strzepek, S. Sander, P. W. Boyd, Global Biogeochem. Cycles 2005 19, GB4S23.

[111] M. Gledhill, P. McCormack, S. Ussher, E. P. Achterberg, R. F. C. Mantoura, P. J. Worsfold, Mar. Chem. 2004, 88,75 .

[112] C. S. Hassler, V. Schoemann, C. M. Nichols, E. C. V. Butler, P. W. Boyd, Proc. Natl. Acad. Sci. 2011, 108, 1076.

[113] C. S. Hassler, E. Alasonati, C. A. Mancuso Nichols, V. I. Slaveykova, Mar. Chem. 2011, 123,88 .

[114] C. S. Hassler, V. Schoemann, Biogeosciences 2009, 6, 2281.

[115] L. Vong, A. Laës, S. Blain, Anal. Chim. Acta 2007, 588, 237.

[116] L. M. Laglera, G. Battaglia, C. M. G. van den Berg, Mar. Chem. 2011, 127, 134.

[117] L. M. Laglera, C. M. G. van den Berg, Limnol. Oceanogr. 2009, 54, 610.

[118] Y. Shaked, H. Lis, Front. Microbiol. 2012, 3.

[119] C. S. Hassler, V. Schoemann, M. Boye, A. Tagliabue, M. Rozmarynowycz, R. M. L. McKay, Oceanogr. Mar. Biol. 2012, 50, 1.

[120] I. Obernosterer, G. J. Herndl, Limnol. Oceanogr. 2000, 45, 1120.

[121] E. M. Thurman, in 'Organic geochemistry of natural waters', Ed. E. Thurman, 1985, p. 273

[122] L. Laglera, G. Battaglia, C. M. G. van den Berg, Anal. Chim. Acta 2007, 599, 58.

[123] K. N. Buck, M. C. Lohan, C. J. M. Berger, K. W. Bruland, Limnol. Oceanogr. 2007, 52, 843.

[124] B. Stolpe, L. Guo, A. M. Shiller, M. Hassellöv, Mar. Chem. 2010, 118, 119.

[125] L. Norman, I. A. M. Worms, E. Angles, A. R. Bowie, C. Mancuso Nichols, A. N. Pham, V. I. Slaveykova, A. T. Townsend, T. D. Waite, C. S. Hassler, Mar. Chem. submitted..

[126] C. S. Hassler, L. Norman, N. C. Mancuso, L. Clementson, C. Robinson, V. Schoeman, R. Watson, M. Doblin, Mar. Chem. 2014, doi: 10.1016/j.marchem.2014.10.002.
[127] C. M. Nichols, S. G. Lardiere, J. P. Bowman, P. D. Nichols, J. A. E. Gibson, J. Guezennec, Microb. Ecol. 2005, 49, 578.

[128] P. Verdugo, A. L. Alldredge, F. Azam, D. L. Kirchman, U. Passow, P. H. Santschi, Mar Chem. 2004, 92, 67.

[129] A. F. D. Kennedy, I. W. Sutherland, Biotechnol. Appl. Biochem. 1987, 9, 12.

[130] S. Steigenberger, P. J. Statham, C. Volker, U. Passow, Biogeosciences 2010, 7, 109.

[131] F. M. M. Morel, A. B. Kustka, Y. Shaked, Limnol. Oceanogr. 2008, 53, 400.

[132] M. Ozturk, P. L. Croot, S. Bertilsson, K Abrahamsson, B. Karlson, R. David, A. Fransson, E. Sakshaug, Deep Sea Res., Part II 2004, 51, 2841.

[133] P. van der Merwe, D. Lannuzel, C. A. M Nichols, K. Meiners, P. Heil, L. Norman, D. N. Thomas, A. R. Bowie, Mar. Chem. 2009 , 115, 163.

[134] C. Schlosser, P. L. Croot, Limnol. Oceanogr. 2008, 6, 630 .

[135] M. Chen, W. X. Wang, L. D. Guo, Global Biogeochem. Cycles 2004, 18

[136] K. Kuma, J. Nishioka, K. Matsunaga, Limnol. Oceanogr. 1996, 41, 396.

[137] A. Tagliabue, K. R. Arrigo, J. Geophys. Res., C: Oceans 2006, 111

[138] A.L.Rose,T.D.Waite,Mar. Chem. 2003, 84, 85 .

[139] M. T. Maldonado, N. M. Price, J. Phycol. 2001, 37, 298.

[140] M. Whitfield, in 'Advances in Marine Biology', Ed. A. J. Southward, P. A. Tyler, C. M. Young, L. A. Fuiman, 2001, p. 1.

[141] W. G. Sunda, S. A. Huntsman, Sci. Total Environ. 1998, 219, 165.

[142] K. Kuma, A. Katsumoto, H. Kawakami, F. Takatori, K. Matsunaga, Deep Sea Res., Part I 1998, 45, 91 .

[143] R. J. Geider, Nature 1999, 400, 815

[144] A. L. Rose, T. D. Waite, Environ. Sci. Technol. 2002, 36, 433 .

[145] A. N. Pham, T. D. Waite, Geochim. Cosmochim. Acta 2008, 72, 3616.

[146] E. G. Roy, M. L. Wells, D. W. King, Limnol. Oceanogr. 2008, 53, 89.

[147] P. L. Croot, A. R. Bowie, R. D. Frew, M. T. Maldonado, J. A. Hall, K. A. Safi, J. La Roche, P. W. Boyd, C. S. Law, Geophys. Res. Lett. 2001, 28, 3425.

[148] J. M. Santana-Casiano, M. Gonzalez-Davila, M. J. Rodriguez, F. J. Millero, Mar. Chem. 2000, 70, 211 .

[149] F. J. Millero, S. Sotolongo, M. Izaguirre, Geochim. Cosmochim. Acta 1987, 51, 793.

[150] L. Emmenegger, R. R. Schonenberger, L. Sigg, B. Sulzberger, Limnol. Oceanogr. 2001, $46,49$.

[151] Y. Shaked, Y. Erel, A. Sukenik, Environ. Sci. Technol. 2002, 36, 460.

[152] T. D. Waite, F. M. M. Morel, Environ. Sci. Technol. 1984, 18, 860.

[153] K. Barbeau, E. L. Rue, C. G. Trick, K. W. Bruland, A. Butler, Limnol. Oceanogr. 2003, $48,1069$.

[154] S. Garg, A. L. Rose, A. Godrant, T. D. Waite, J. Phycol. 2007, 43, 978.

[155] A. L. Rose, D. Waite, Geochim. Cosmochim. Acta 2006, 70, 3869

[156] A. L. Rose, T. D. Waite, Environ. Sci. Technol. 2005, 39, 2645.

[157] A. L. Rose, T. P. Salmon, T. Lukondeh, B. A. Neilan, T. D. Waite, Environ. Sci. Technol. 2005, 39, 3708.

[158] M. L. Wells, N. M. Price, K. W. Bruland, Mar Chem. 1995, 48, 157.

[159] R. J. M. Hudson, F. M. M. Morel, Deep Sea Res., Part I 1993, 40, 129.

[160] I. Worms, D. F. Simon, C. S. Hassler, K. J. Wilkinson, Biochimie 2006, 88, 1721.

[161] P. L. Croot, M. I. Heller, Front. Microbiol. 2012, 3 .
[162] R. J. M. Hudson, Sci. Total Environ. 1998, $219,95$.

[163] M. Pahlow, U. Riebesell, D. A. Wolf-Gladrow, Limnol. Oceanogr. 1997, 42, 1660.

[164] W. J. Pasciak, J. Gavis, Limnol. Oceanogr. 1974, 19, 881 .

[165] T. P. Salmon, A. L. Rose, B. A. Neilan, T. D. Waite, Limnol. Oceanogr. 2006, 51, 1744.

[166] Y. Shaked, A. B. Kustka, F. M. M. Morel, Limnol. Oceanogr. 2005, 50, 872.

[167] F. Visser, L. J. A. Gerringa, S. J. Van der Gaast, H. J. W. De Baar, K. R. Timmermans, J. Phycol. 2003, 39, 1085.

[168] M. T. Maldonado, A. E. Allen, J. S. Chong, K. Lin, D. Leus, N. Karpenko, S. L. Harris, Limnol. Oceanogr. 2006, 51, 1729.

[169] C. Hassler, unpublished data.

[170] M. T. Maldonado, N. M. Price, Deep Sea Res., Part II 1999, 46, 2447.

[171] J. Morrissey, C. Bowler, Front. Microbiol. 2012, 3.

[172] G. Sarthou, K. R. Timmermans, S. Blain, P. Tréguer, J. Sea. Res. 2005, 53, 25.

[173] B. S. Twining, S. B. Baines, Ann. Rev. Mar. Sci. 2013, 5, 191

[174] R. Boyanapalli, G. S. Bullerjahn, C. Pohl, P. L. Croot, P. W. Boyd, R. M. L. McKay, Appl. Environ. Microbiol. 2007, 73, 1019.

[175] C. S. Hassler, M. R. Twiss, Environ. Sci. Technol. 2006, 40, 2544.

[176] C. S. Hassler, M. R. Twiss, R. M. L. McKay, G. S. Bullerjahn, J. Phycol. 2006, 42, 324.

[177] O. Gillor, O. Hadas, A. F. Post, S. Belkin, Freshwater Biol. 2010, 55, 1182.

[178] N. V. Ivanikova, R. M. L. McKay, G. S. Bullerjahn, Limnol. Oceanogr. 2005, 3, 86.

[179] R. J. M. Hudson, F. M. M. Morel, Limnol. Oceanogr. 1990, 35, 1002.

[180] C. Volker, D. A. Wolf-Gladrow, Mar. Chem. 1999, 65, 227.

[181] J. A. Raven, New Phytol. 1990, 116, 1.

[182] R. F. Strzepek, P. J. Harrison, Nature 2004, $431,689$.

[183] J. Laroche, H. Murray, M. Orellana, J. Newton, J. Phycol. 1995, 31, 520.

[184] M. A. van Leeuwe, J. Stefels, J. Phycol. 1998, 34, 496.

[185] P. W. Boyd, A. C. Crossley, G. R. DiTullio, F. B. Griffiths, D. A. Hutchins, B. Queguiner, P. N. Sedwick, T. W. Trull, J. Geophys. Res., C: Oceans 2001, 106, 31573.

[186] W. Cheah, A. McMinn, F. B. Griffiths, K. J. Westwood, S. W. Wright, L. A. Clementson, PLOS ONE 2013, 8, e72165.

[187] D. J. Sugget, N. Stambler, O. Pràsil, Z. Kolber, A. Quigg, E. Vàsquez-Dominguez, T. Zohary, T. Berman, D. Iluz, O. Levitan, T. Lawson, E. Meeder, B. Lazar, E. Bar-zeev, H. Medovà, I. Berman-Frank, Aquat. Microb. Ecol. 2009, 56, 227.

[188] C. Kaiblinger, M. Dokulil, Photosynth. Res. 2006, 88, 19.

[189] L. Poorvin, S. G. Sander, I. Velasquez, E. Ibisanmi, G. R. LeCleir, S. W. Wilhelm, J. Exp. Mar. Biol. Ecol. 2011, 399, 43.

[190] M. J. A. Rijkenberg, L. J. A. Gerringa, K. R. Timmermans, A. C. Fischer, K. J. Kroon, A. G. J. Buma, B. T. Wolterbeek, H. J. W. de Baar, Mar. Chem. 2008, 109, 29.

[191] T. Y. Ho, A. Quigg, Z. V. Finkel, A. J. Milligan, K. Wyman, P. G. Falkowski, F. M. M. Morel, J. Phycol. 2003, 39, 1145.

[192] E. Breitbarth, E. P. Achterberg, M. V. Ardelan, A. R. Baker, E. Bucciarelli, F. Chever, P. L. Croot, S. Duggen, M. Gledhill, M. Hassellöv, C. Hassler, L. J. Hoffmann, K. A. Hunter, D. A. Hutchins, J. Ingri, T. Jickells, M. C. Lohan, M. C. Nielsdóttir, G. Sarthou, V. Schoemann, J. M. Trapp, D. R. Turner, Y. Ye, Biogeosciences 2010, 7, 1075. 